or whether we should have private rooms with a single man in a room. The federal government in the new standards adopted as to how houses shall be built has set a high-water mark in that respect, which is going to be of value to the country for generations after the war is over. One of the interesting by-products of the war is the disappearance of the bunk house, the establishment of the right kind of hotels for single men and women, the declaration against the tenement house, and the preference for the small house as the normal domicile of the American working-man.

We hope that out of the situation will come the formulation of a national policy with regard to the housing of the working people of this country. The time has come when the people of this country should consider the question of a national policy for the housing of its workers. It is a great mistake to go on as in the past, housing people as animals, and with a sort of laissez faire policy that everything will come out all right. We have had too many concrete demonstrations of the fact that it does not come out all right, to let us be content with that sort of practice. So one of the things that is going to come out of this awakened interest in housing, because of dramatic war-time manifestations of its fundamental importance, is undoubtedly a wider recognition by the people of the whole United States of the fact that as are the homes of the people so is the citizenship of the country.

\title{
THE MOBILIZATION OF WOMEN
}

\section{By Mrs. Nevada Davis Hitchcock,}

Pennsylvania State Chairman, Home Economics, National League for Woman's Service.

Women responded all over the country when war was declared by President Wilson. Their patriotism was manifested in various ways. The desire to serve their country was shown by organizations already engaged in war work pledging renewed energy and extended fields of service. Such organizations are the Red Cross, Emergency Aid and Navy League. Women's clubs and associations all over the United States offered their services to President Wilson with such an avalanche of letters and telegrams that our President saw this was 
no matter for one man to handle alone even if he were able to take care of the rest of the country. With his usual wisdom he turned the matter over to the Council of National Defense with the result that the Woman's Committee of the Council of National Defense was formed as a clearing house for women's activities all over the United States. The selection of a chairman for this great body was most fortunate because in Dr. Anna Howard Shaw they have a woman who not only understands organization, but one who stands as an ideal of democracy. She has not only the admiration of both men and women for her intellectual ability, but she also possesses their confidence in regard to common sense and good judgment.

As has been said, the Woman's Committee of the Council of National Defense is intended to be a clearing house between women's clubs and organizations and the United States government. The object is twofold-first, to give out patriotic inspiration, second, to furnish educational assistance. In order to accomplish this a number of departments have been formed. The work is carried on by state divisions which in turn work through county committees. Each county committee has ten departments with a director in charge. The scope of these embraces registration, food production, food conservation, women in industry, child welfare, maintenance of social agencies, education, liberty loan, foreign relief, and the safeguarding of moral and spiritual forces. Under the department of registration a system has been established by which it is expected to have listed and entered in a cross-indexed file the name, address and qualifications of every woman in the country. If a woman is already employed there is no intention of disturbing her, but should she be desirous of obtaining a position either volunteer or salaried, the Registration Department will try to find a suitable niche where her special qualifications will be used to the greatest possible advantage.

The departments of food production and food conservation are most important. Under food production we have the land army units which have become so great in number that they require study as a separate division. The work done under food conservation also is in a class by itself and will be touched upon later. The Council of National Defense recognizes that child welfare needs special attention at this crucial period in our history. At this time women are going into industry, because they must take the place of men who 
are in the trenches. Family life is more or less disorganized. Children are in danger of becoming weak morally and physically; morally because they are allowed to run the streets, and to take care of themselves to a greater degree; physically because their mothers are unable to secure and prepare the proper food owing to the necessity of working away from home and the increased cost of living. Child welfare and women in industry are insolubly linked.

Under women in industry the relations between employer and employe are studied and often adjusted by the Woman's Committee through women's associations which aid in securing proper sanitary conditions, equal wages for equal work and the protection of women against unwise zeal and enthusiasm of taking positions where they are not yet needed. The other departments have been carried on with equal zeal and enthusiasm by the committee.

The National League for Woman's Service stands in a position by itself. It had just been formed when war was declared by our President. As an outgrowth of the work of the National Patriotic Relief Committee during the Mexican crisis a plan was formed for the mobilization of the woman force of this country and Miss Grace Parker was sent to England to see what the women were doing over there. She found that in munition plants alone over a million and a half girls and women were employed. They also take the places of men as porters, conductors, letter carriers, street sweepers, telegraph messengers, lamp lighters, chimney sweeps, clerks in grocery shops, carpenters, cab drivers, window cleaners, etc.; they are, in fact, in every department of industry.

Miss Parker learned from English women that the great handicap of many thousands of women for nursing, industrial, social and welfare work was lack of training and experience. To meet this need women's organizations were formed in England with such success that Miss Parker returned to America with a plan for mobilization of American women based on the English women's organizations. At the invitation of the National Security League this plan was presented in Washington at the Congress of Constructive Patriotism on January 26, before one thousand delegates from all over the United States. It met with instant approval and the National League for Woman's Service was organized by the delegates present with Miss Maud Wetmore as Temporary National Chairman. Service and training are the keynotes to the work of the National 
League. In time of war the object is to supplement the work of the Red Cross, the army and the navy, and to deal with questions of women's work and welfare. The outline of organization in each state consists of a state executive committee and county committees similar to that of the Woman's Committee of National Defense. The work is carried on through state divisions for service training along the following lines: social and welfare work, home economics, agriculture, industry, medicine and nursing, motor driving, general service, health and overseas relief.

Under the social and welfare work comes the canteens; emergency, temporary and permanent. The military canteen fills a great need. Many things are accomplished that supplement the care of the government for our men. The morale of a camp may be improved by the application of cake and ice-cream oftener than the commanders realize. Under general service comes training as stenographers, file clerks, record clerks, telegraph operators, telephone switch-board operators, signalling, map reading and wireless. The work of the league may be divided into two groups, volunteer and professional. The volunteer group is divided again into two groups, specialized and general service. To do specialized work one must be well qualified, as the league accepts no woman for specialized service who is not efficiently trained. Under general service there is a vast amount of work which any woman may do who desires service and understands the needs of others. In agriculture the National League has not only formed many land army units, but also has helped to establish training schools or farms where women receive free training in agricultural pursuits. Service houses are a part of the league activities that require special mention. These houses are, as their name implies, for service in that part of the community in which they are placed. They offer training along the lines enumerated above and are open for day and night classes. Philadelphia has four service houses.

The motor division is a most important one. Only women who have good hearts and good eyes are permitted to enter. They must be excellent drivers and be able to get under their cars and make their own repairs. The splendid work of the Motor Corps in New York has a wide reputation. Philadelphia has a Motor Messenger Corps which is an independent body and not connected with either the League or Council of Defense. 
Americanization of the immigrant women is also part of the work done by the National League for Service. It is impossible to have a unity of American ideals when we have so many foreign born women who cannot speak English.

Women have been turning their attention to agriculture for some years. It needed, however, the stress for further food productions to mobilize them. As a result of work done by English and Canadian women we have the Women's Land Army of America. In England the daughters of practically every county family in the United Kingdom have taken up work on their own farm lands side by side with the village agricultural laborers. Titled women, formerly well known in the hunting field and in the world of sport, work in the dairy farms and in the stables. In many cases women of delicate health who have taken up work on the land have been thereby restored to health. In this country the work of the Women's Land Army was started by voluntary organizations, among which were the National Land Council and the Women's National Land Service Corps. When later the Board of Agriculture took over the work and drew up an elaborate scheme of organization consisting of war agricultural committees in every county and of women's agricultural committees, these organizations were united under the women's branch of the Food Production Department of the board. The women who volunteer for this service bind themselves to go where the board sends them during the period of the war. In return for their service they receive one free outfit, free training with maintenance for a period of not more than three weeks, maintenance between periods of employment not exceeding four weeks, and a wage of 18 cents per week or the standard wage of the district where they work, whichever is the higher. Miss Helen Fraser gives the numbers of this Land Army as "over 258,300 whole and part time workers."

The reluctance of the farmers to employ women was a serious obstacle to their introduction in large numbers on the land, and available openings were at finst limited. And it is a satisfactory feature of the work of the Women's Land Army that farmers who in the beginning were strongly opposed to the employment of women have in many cases become converts, owing to the success of the women as agricultural workers. The unit plan of organizations has been adopted in most places. The essence of this is that the women workers live in a community, under a captain or supervisor, 
with a system of coöperative housekeeping, and go out from this center in squads to work on neighboring farms or estates. This relieves the farmer's wife of the burden of feeding the extra laborers.

One of the organizations which is doing wonderful work in extended fields is the Y. M. C. A., with its hostess houses and social work at military camps. It is a link between the soldier and his family and a protection to both girls and boys. The Home Service Department of the Red Cross, the mother's clubs of the army and navy all are well known and are doing a splendid service in looking after the families of soldiers and sailors as well as providing surgical dressings and knitted goods. The General Federation of Women's Clubs has taken up a distinct work in establishing hostess houses in the south of France where our American soldiers can go for rest, recreation and comfort when they have a furlough from the front. Every women's club was asked to subscribe a dollar for each member. There is no doubt but that many will do more than that, for women realize the vital need of such places if we are to have our boys come back to us healthy and sane.

Some independent organizations are worthy of mention, such as that in a southern state where the women who went through the Civil War have formed a unit called the Girls of Sixty-one. These women, most of them near the eighty mark in years, go out to the camps and mend, sew and darn for the boys who are far from home. Some of the boys come from Washington and Oregon. They are devoted to these belles of the Civil War.

The unnoticed mobilization of one great class of American women has been of inestimable value, that of the teachers in our public schools. Few other women have been called upon to do the work laid before this body of instructors who have given daily devotion to the cause. Every truth, every effort intended to reach the public has been with one accord turned over to them. When a drive has been contemplated, without exception some one says, "Oh, the way to reach people is through our schools," and immediately the work is turned over to them. The teachers vie in popularity in the minds of certain leaders, with women's clubs. Enough work is heaped upon the active members of women's clubs to keep them busy twenty-four hours a day. The same thing is true of our teachers. In the elementary grades we have had food conservation, thrift stamps, war savings stamps, liberty loans, war gardens, and 
junior Red Cross (a chapter in each class, knitting squares for blankets). The sewing classes have been making garments for Belgians; Camp Fire Girls and Girl Scouts are supervised; Red Cross units are formed in the High and Normal Schools;-canning and dehydration are taught in the domestic science sections. During the third liberty loan drive each school in Philadelphia had its quota, being $\$ 1,500$ for each class. In one building the entire quota was $\$ 57,000$. This school raised $\$ 200,000$. Is it any wonder that one teacher said, "That week I taught a little arithmetic, a bit of physiology, some spelling and a great deal of patriotism." Yet the teachers must cover the course of prescribed studies and do all this extra work without fame, honor or extra pay. The laborer is worthy of his hire even in war time and I make a plea that this fine body of women get at least justice in that line.

In looking over the mobilization of women in war time one must not forget that great line of defense, the women who keep the home fires burning. They do not follow the flag and fife, they have no public honor or applause, but a wonderful mobilization has taken place, the silent mobilization of the housewife, (one may add this does not mean the mobilization of silent housewives). The first step was the signing of the food cards pledging allegiance to Mr. Hoover. Millions of these cards were signed. More than 350,000 were turned in, in Philadelphia alone, and over 700,000 in the state of Pennsylvania. This mobilization includes the women who have the right to wear service pins and show service flags. I would not suggest in any way that the men of this country are not suffering keenly because their sons are away. But I do believe that women have a clearer visualization and keener imagination of what their boys are going through, and I know that the woman shut within four walls does not have the things that will help distract her mind and keep her from worrying that the man does who goes out of his home each day and for that reason I wish to emphasize the wonderful courage of women who are expecting either a telegram or cablegram every time the door bell rings. With wonderful courage they are keeping their homes, helping with Red Cross and food conservation, knitting, sewing, making bandages-writing to the boys, and above all showing a spirit of comradeship to other mothers and home-makers that marks neither caste nor station. The work they do is none the less efficient because they have neither captains 
nor directors. They are the great rank and file held together by the bond of love for children and country.

There has been of course some duplication, some overlapping of lines of work by the different organizations, but the amount of work to be done and the need of workers is so great, that any duplication of effort is far outweighed by the service rendered. The lasting results of this mobilization will lay the foundation for future cooperation along the line of true democracy. Women of all creeds and beliefs, nationalities and classes, have learned to work side by side and shoulder to shoulder with the same inspiration in heart and mind. The one great outstanding fact already apparent is that all classes, rich and poor, trained and untrained, are learning the sublime value of work. The call of patriotism has brought forward the woman who did not know that there was any need for her to work, the woman who did not know she could work, and lastly the woman who considered herself in the favored class exempt from work, whether there is any need of it or not. When the war is over and the mobilization will be no longer needed, the habit of service and the respect for work will have become so firmly fixed in the minds of American women that none of them will be willing to be idle drifters untrained and undirected, or parasites upon the public body. The American woman will never surrender the habit of service to her country. 